\title{
Application of Electrodialysis Process for Reduction of Electrical Conductivity and COD of Water Contaminated By Composting Leachate
}

\author{
Nazila Parsa ${ }^{\text {a }}$, Golnoosh Khajouei ${ }^{\text {b }}$, Mohammadali Masigol ${ }^{c^{*}}$, Hasti Hasheminejad ${ }^{\mathrm{d}}$, \\ Ahmad Moheb ${ }^{\text {a }}$ \\ ${ }^{a}$ Department of Chemical Engineering, Isfahan University of Technology, Isfahan, Iran. \\ ${ }^{b}$ Department of Civil and Environmental Engineering, West Virginia University, Morgantown 26505, USA. \\ ${ }^{c}$ Department of Chemical Engineering, Kansas State University, Manhattan, Kansas 66502, USA. \\ ${ }^{d}$ Department of civil Engineering, Isfahan University of Technology, Isfahan, Iran. \\ Received 18 February 2018; Accepted 19 May 2018
}

\begin{abstract}
The presented paper describes an experimental study to reduce electrical conductivity (EC) of composting leachatepolluted water by using electrodialysis (ED) process. High efficiency, simple operation, low waste generation and selectivity are considered as major advantageous of applying ED process. Along with evaluation of ED method for desalination, the possibility of the process for COD (chemical oxygen demand) removal was also studied. The impact ofapplied voltage, feed concentration and process time on ED performances were investigated. Increasing of the applied voltage and decrease of feed concentration enhanced the reduction of EC and improved the COD removal from the sample. At optimal condition (Voltage $=10$ Volt, feed solution=Cf/4 and time operation=120 min), the reduction of EC and COD removal were $92.7 \%$, and $83.8 \%$, respectively. Applying higher voltage and using more feed solution concentrations resulted in more energy consumption. The obtained results showed that ED method can be considered as an acceptable method to reduce salt and organic content.
\end{abstract}

Keywords: Electrodialysis; Electrical Conductivity; COD; Membrane; Composting Leachate-Polluted Water.

\section{Introduction}

Along with considerable benefits of composting process, which is a technology for converting organic matter to organic fertilizer, there is always rise of high different types of biodegradable and non-biodegradable contaminants within the process [1]. Consequently, release of leachate without proper treatment pose serious threads to the environment and human health $[1,2]$.

Although there are several biological and physic-chemical methods to treat leachate, due to the complex composition of leachate, conventional treatment processes are not promising enough for the treatment of this kind of wastewater [35]. In recent years, advanced oxidation processes have been widely used as an alternative method for treatment of refractory wastewater [5-7]. In our previous experience, the performance of Electro-Fenton (EF)-which is an advanced oxidation method-for reduction of chemical oxygen demand (COD) from composting leachate-polluted water was investigated. Results illustrated a COD removal efficiency (up to 50\%) in optimal condition which obtained at initial $\mathrm{pH}$ of 3, current of $3 \mathrm{~A}, \mathrm{H}_{2} \mathrm{O}_{2}$ concentration of $10 \mathrm{~mL}$ and process time of $60 \mathrm{~min}$.

However, during EF method, the electrical conductivity of the water increased from 5 to $15 \mathrm{mS} / \mathrm{cm}$. Since there is a

* Corresponding author: masigol@ksu.edu

http://dx.doi.org/10.28991/cej-0309154

$>$ This is an open access article under the CC-BY license (https://creativecommons.org/licenses/by/4.0/).

(C) Authors retain all copyrights. 
standard limitation for conductivity of wastewater to be discharged into the sewage system or surface water, the conductivity needs to be reduced before dumping [8].

In the current study, application of electro-dialysis which is a type of electrochemical membrane process on electrical conductivity reduction was evaluated. ED process is able to concentrate and separate ions from wastewater [8] and could be efficient on EC reduction. Also, because of not very high COD reduction efficiency (50\%) obtained with electrofenton method, along with EC, COD reduction during ED process was evaluated.

There are many applicable processes to reduce salinity such as ion exchange, electrodialysis (ED), reverse osmosis (RO), crystallization and nanofiltration (NF). RO and NF are known as pressure driven membrane processes and need a quite complex pre-treatment to reduce membrane fouling which leads to high capital cost of the process. Moreover, RO technology is ion uncontrollable and relying on size of molecules [9].

However, ED process has several advantages over other separation methods. It doesn't generate large amount of waste, and use hazardous solvent. In addition, ED doesn't suffer from short lifetime of absorbent [10]. ED also offers simple operation, low chemical consumption, appropriate selectively for ion separation, high product recovery [11-16]. Similar to other membrane technologies, membrane fouling is a main obstacle of ED technology [17]. Fouling in ED leads to an increase in cell resistance which consequently decreases ion migration and selectively [8]. However, this problem can be addressed by different methods such as applying struvite crystallization pre-treatment to ED [8], or by combination of ion exchange membrane (IEM) and ultrafiltration (UF) membrane [16].

ED process is a combination of conventional ion exchange technology with membrane technology for removing ions (electrically charged particles) from one solution (known as diluted compartment) to another (concentrated compartment) through selective semi permeable ion exchange membranes (IEMs) by introducing an electrical field [1820]. ED cell consists cation and anion exchange membranes (CEM and AEM) which are the main component of cell and placed alternatively between on pair cathode and anode. These membranes partition electrolyte into segments [15, 21]. By applying an electrical potential to the cell, charged particles (negative or positive) in the electrolyte move towards the electrodes with the opposite charge, consequently, ionic concentration will increase in some compartment and deplete in the adjacent ones [12, 21, 23].

ED has been successfully applied for different purposes such as: removal of hardness [12-14], separation of ionic species [21, 24], recovery of beneficial products (e.g. PO4-P and NH4-N) from effluents [8, 9, 22, 23, 25] and desalination [9, 15, 26, 27]. ED can also be implemented for the treatment of industrial wastewater [17, 28] such as reducing electrical conductivity from almond industry [29], chloride removal from wet flue gas desulfurization wastewater [28], or removal of harmful ions such as $\mathrm{F}^{-}, \mathrm{NO}_{3}{ }^{-}, \mathrm{CL}^{-}$and $\mathrm{Br}^{-}$and heavy metals such as $\mathrm{pb}^{2+}, \mathrm{Ni}^{2+}, \mathrm{Cu}^{2+}$, $\mathrm{Cr}^{3+}, \mathrm{Mn}^{2+}, \mathrm{Fe}^{3+}$, etc. [31, 32].

ED has also been studied for other applications, such as removing chromium (VI) from aqueous solutions using a novel hybrid liquid membrane [33], processing a solution of lithium chloride containing organic solvents [34] and concentrating $\mathrm{NaCl}$ from seawater reverse osmosis brines for the chlor-alkali industries [35]. Additional functions include selective separation of mono and di-valent cations during brackish water desalination [36], purification of pentoses from hemicellulosic hydrolysates with sulfuric acid recovery [37], purification of $\mathrm{H}_{2} \mathrm{SO}_{4}$ of Pickling Bath contaminated by $\mathrm{Fe}$ (II) Ions [38], and Synthesis and transport of impurities and production of choline dihydrogen phosphate [39, 40].

According to the ED principles, by applying electric potential to the ED cell containing wastewater, cations and anions existing in the feed solution pass through the CEM and AEM toward the cathodic and anodic compartments, respectively. It is expected for feed compartment to be depleted from the ions as time goes on. By this mean, the hardness of feed solution is reduced. Additionally, the electric field makes a situation for transfer of acidic organic materials to ions which pass through CEM and AEM from diluted (feed) to the concentrated compartments. Thus, it leads to COD reduction of feed compartment [23].

\section{Experimental Section}

\subsection{Materials and Methods}

All samples were leachate-contaminated water, which was taken from Esfahan Composting Plant (ECP), Iran. Samples containing raw and pre-treated wastewater were analyzed to determine the EC, COD, BOD, and TDS (Table 1). EC was measured using water quality meter (Model 8603) and COD was measured by using "closed reflux method" according to standard methods. All samples were stored at $4^{\circ} \mathrm{C}$ until use. An ED set up containing three cylindrical compartments was made from plexiglass, owing to its proper resistance to acid, base and feed solutions and all compartments had equal thickness of $10 \mathrm{~mm}$. The compartments were separated by a pair of CEM and AEM. Effective area of each membrane was $9.5 \times 4.5 \mathrm{~cm}^{2}$. The anion and cation exchange membranes used in this work were AR204SXR412 and CR67, MK111 (Ionics, MA, USA), both supplied by Arak Petrochemical Complex. Main properties 
of the membranes have been listed in Table 2.

Table 1. The characteristics of raw and pre-treated wastewater

\begin{tabular}{ccc}
\hline Parameters & Raw wastewater & Pre-treated wastewater \\
\hline EC (mS/cm) & $5-6$ & $11-15$ \\
COD (mg/L) & 12,000 & 4500 \\
BOD (mg/L) & 7500 & 1600 \\
Turbidity (NTU) & 142 & 112 \\
Colour & Dark-brown & Light-brown \\
TDS (mg/L) & 8875 & - \\
\hline
\end{tabular}

Table 2. Properties of the anion and cation exchange membrane

\begin{tabular}{ccc}
\hline \multirow{2}{*}{ Specification } & \multicolumn{2}{c}{ Membrane } \\
\cline { 2 - 3 } & AR204SXR412 & CR67, MK111 \\
\hline Matrix structure & $\begin{array}{c}\text { Homogeneous polystyrene } \\
\text { DVB copolymer }\end{array}$ & $\begin{array}{c}\text { Homogeneous polystyrene } \\
\text { DVB copolymer }\end{array}$ \\
Specific Weight (mg/cm $\left.{ }^{2}\right)$ & 13.7 & 13.7 \\
Thickness (mm) & 0.5 & 0.5 \\
Burst Strength (kg/cm $\left.{ }^{2}\right)$ & 7.0 & 7.0 \\
Water Content & $46 \%$ of wet resin only & 2.4 \\
Capacity (meq/dry gram resin) & 2.8 & $1-10$ \\
Chemical stability, pH & $1-10$ & 2.4 \\
\hline
\end{tabular}

\subsection{Experimental Procedures}

Before each experiment, per-treatment of membranes was performed to remove impurities and stabilize them. In this regard, AEM and CEM were dipped into the $1 \mathrm{M} \mathrm{NaOH}$ and $1 \mathrm{M} \mathrm{HCl}$ solutions, respectively, for two hours and washed with distilled water. As a result, the anion and cation exchange membranes were changed to hydroxide and hydrogen form. Platinum-coated titanium and nickel mesh (supplied by Niroocholer Co, Esfahan, Ira) which had the same effective area as membranes, were used as the anode and cathode, respectively. Adjustable DC power supply (Star 305, Iran) was utilized to apply electric potential difference to the cell. It could supply the desired voltage and direct current in the range of 0-40 Volt and 0-4 A, respectively. The experiments were performed at ambient temperature and batch mode. Firstly, the reservoir tanks of electrode rinse solutions were fed with 1 litter of $0.02 \mathrm{M} \mathrm{H}_{2} \mathrm{SO}_{4}$ and 1 litter of $0.02 \mathrm{M} \mathrm{HCl}$ solution. Then the feed tank was filled with $400 \mathrm{ml}$ of wastewater and solutions were circulated by proper pumps through the compartments. For each experiment, fresh solutions were used. Afterward, appropriate voltage was applied, and experiment was started. All the experiments were conducted for 120 minutes at constant voltage and samples of feed solution were taken every $30 \mathrm{~min}$. A schematic diagram of the experimental set up for ED is illustrated in Figure1. 


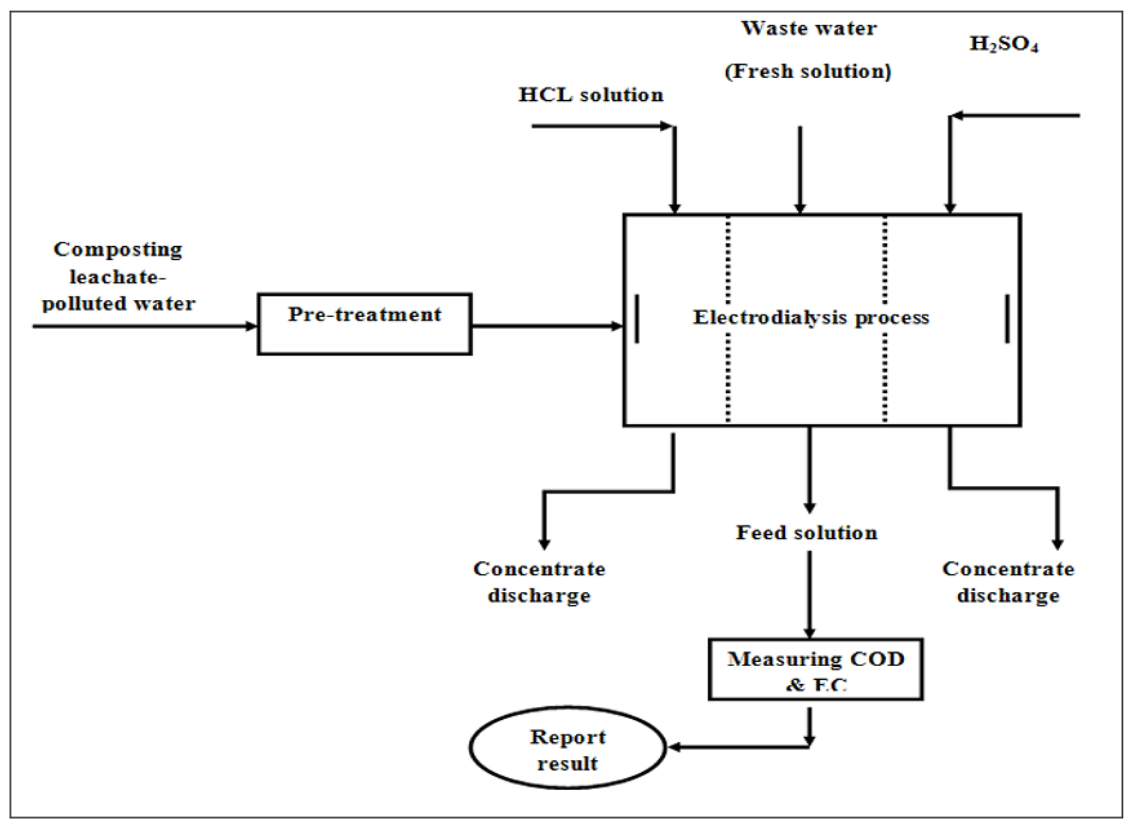

Figure 1(A). A schematic diagram of the experimental set up for ED method

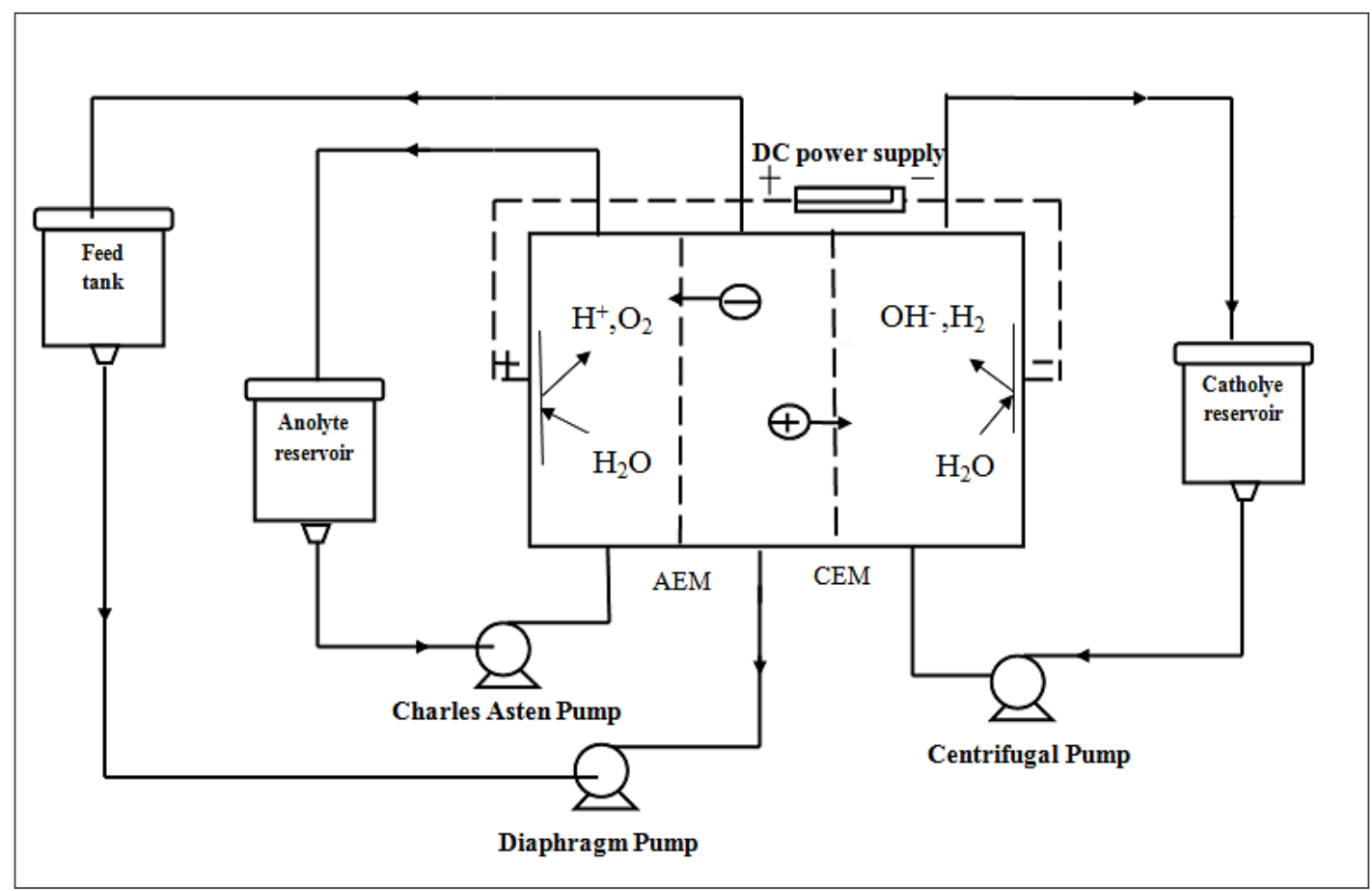

Figure 1(B). Batch mode experimental set-up of ED system, electrodialysis process (three-compartment cell) with the Anion exchange and Cation exchange membrane

\subsection{Calculation}

In this study, ED performances such as energy consumption, efficiency of COD reduction, and EC reduction in the term of some operating parameters (voltage, concentration, time) were evaluated. Removal efficiency of COD indicated the percentage of organic load removed from the feed solution and it is determined by using the following equation:

$$
\eta=\frac{\mathrm{COD}_{0}-\mathrm{COD}_{\mathrm{t}}}{\mathrm{COD}_{0}} \times 100
$$

Where $\mathrm{COD}_{0}(\mathrm{mg} / \mathrm{L})$ and $\mathrm{COD}_{\mathrm{t}}(\mathrm{mg} / \mathrm{L})$ are COD of feed solution at time zero and $\mathrm{t}$, respectively. Energy consumption can be described as energy needed for electrolysis cell and was calculated via following equation:

$$
E=\frac{\int_{0}^{t} V I d t}{V_{D}}
$$


Where E, V, I, t and $V_{D}$ are energy consumption (W.hr/L-1), applied voltage (Volt), cell current (A), operation time and initial volume of diluted compartment (L) respectively [18, 41, 43]. Further, the reduction of EC is defined as following equation:

$$
\mathrm{EC} \%=\frac{\mathrm{EC}_{0}-\mathrm{EC}_{\mathrm{t}}}{\mathrm{EC}_{\mathrm{t}}} \times 100
$$

Where $\mathrm{EC}_{0}(\mathrm{~ms} / \mathrm{cm})$ and $\mathrm{EC}_{\mathrm{t}}(\mathrm{ms} / \mathrm{cm})$ are electro conductivity of feed solution at time zero and $\mathrm{t}$, respectively.

\section{Results and Discussions}

Different operating parameters can affect the performance of an ED process. Operation parameters considered in this research were: applied voltage $(5,10,15$ and 20 Volt), concentration of feed solution, which was considered $\mathrm{Cf}$ when no dilution was done and $\mathrm{Cf} / 2$ and $\mathrm{Cf} / 4$ when the feed solution diluted twice and quadruplicate, respectively) and process time $(30,60,90$ and120 $\mathrm{min})$.

\subsection{Effect of Applied Voltage on EC and COD Removal}

To investigate the effect of voltage, the experiments were conducted with $400 \mathrm{~mL}$ initial volume of feed solution at ambient temperature for $120 \mathrm{~min}$. Anolyte and catholyte reservoirs consisted the $0.02 \mathrm{M} \mathrm{H}_{2} \mathrm{SO}_{4}$ and $0.02 \mathrm{M} \mathrm{NaOH}$ solutions, respectively. Limiting current (LC) is an important factor which determines current utilization and electrical resistance in an ED cell. Prior to doing any ED experiment, LC should be investigated to see its influence on the cell performance. In high levels of voltage, sometimes ions depletion occurs at the membrane interface of the feed compartment. Current density at this moment is called LC. This chemical phenomenon which is known as concentration polarization results in reduction of ions transfer through the membrane. Existence of a point of inflection in the plot of voltage against the current shows the occurrence of concentration polarization [44, 45]. Performing ED below the limiting current is desirable [18, 20]. Here, our preliminary experiments were attributed to study the concentration polarization in the proposed ED cell considering all levels of applied voltage. As Figure 2 shows, for all concentration levels, electrical current increased with increase of applied voltage and no inflection point was observed. This directly indicates that no concentration polarization occurs in the ED cell in the range of voltages that studied in this research $(5-20 \mathrm{~V})$.

As the first step to evaluate the ED performances, the ability of the proposed setup to reduce the conductivity of samples was studied. Figure 3 describes the variation of "conductivity reduction" as a function of applied voltage. The ED setup can decrease the sample conductivity up to $90 \%$. As illustrated, when voltage increased, "conductivity reduction" efficiency of feed chamber enhanced. This can be explained by considering the fact that by applying more voltage to the ED cell, more electric field and consequently more potential difference (driving force) for transfer of ions through membranes is provided. This ultimately enhances the EC reduction ability of the device. Considering all voltage levels, as time goes on, the EC reduction rate will be less because with the passage of time more ions are migrated from feed compartment so concentration of ions in feed chamber decreased (high electrical resistance). Consequently, at the constant voltage, lead to lower electrical current, higher driving force would be needed to transfer remained ions. Furthermore, according to the above reason, for all voltage levels at the initial time, EC\% was augmented sharply. Also, it was observed that at the beginning of the process, increasing applied voltage had no effect on conductivity of feed compartment. It can be explained by the fact that although the driving force increased, the number of ions can pass through membranes is limited.

The next step was to study the efficiency of ED process toward COD reduction. According to Figure 4.a, as applied voltage was increased, due to increment of driving force, the percentage of "COD reduction" increased from $37 \%$ in voltage of 5 to $84 \%$ in voltage of $20 \mathrm{~V}$. In other word, dissociated acidic organic materials in feed solution are transformed to the ions under the generative electrical field. These ions are transferred through ion-exchange membranes from feed to the concentrated solution [46]. Besides, no significant change in COD was observed for different voltages after $120 \mathrm{~min}$. Figure 4.b represents the variation of the current density with time for different values of applied voltage. Increasing the applied voltage provided more driving force for ions to transfer through the membranes. This ultimately increases the current density. As time goes on, more ions migrate toward the anolyte and catholyte chambers, the feed compartment is more depleted, so electrical resistance was augmented and as a consequence, overall cell current density decreased. Feed compartment has major contribution of current density in an ED cell.

The energy consumption should always be considered as a critical parameter in the ED process. Figure 5 indicates the variation of energy consumption with applied voltage for different feed concentrations. SPC increased as higher voltage applied to the ED setup. Energy dissipation in the form of heat generation which is directly affected by using higher values of voltage, ultimately increases the temperature. In this case more energy is needed to achieve reasonable EC/COD reduction efficiency. Besides, sometimes, higher temperature destroys the functionality of the membranes. Considering all figures here, since voltage can affect the EC/COD reduction ability of ED setup (positively) and energy consumption of the cell (negatively), there is a trade-off for choosing the optimum value for voltage to be applied to the ED cell. Both positive and negative impacts of voltage is needed to be considered to design an optimum ED process. The proposed ED method should meet the reduction efficiency requirements while considering energy limitations [4749]. 


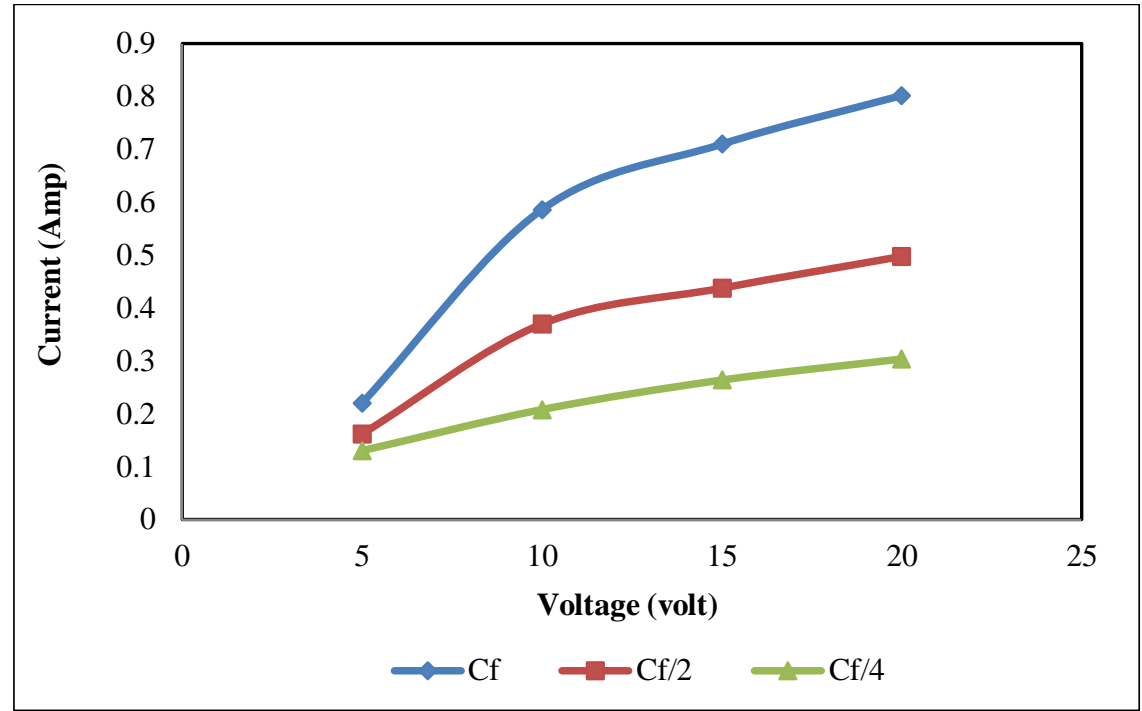

Figure 2. Variation of averaged current with applied voltage

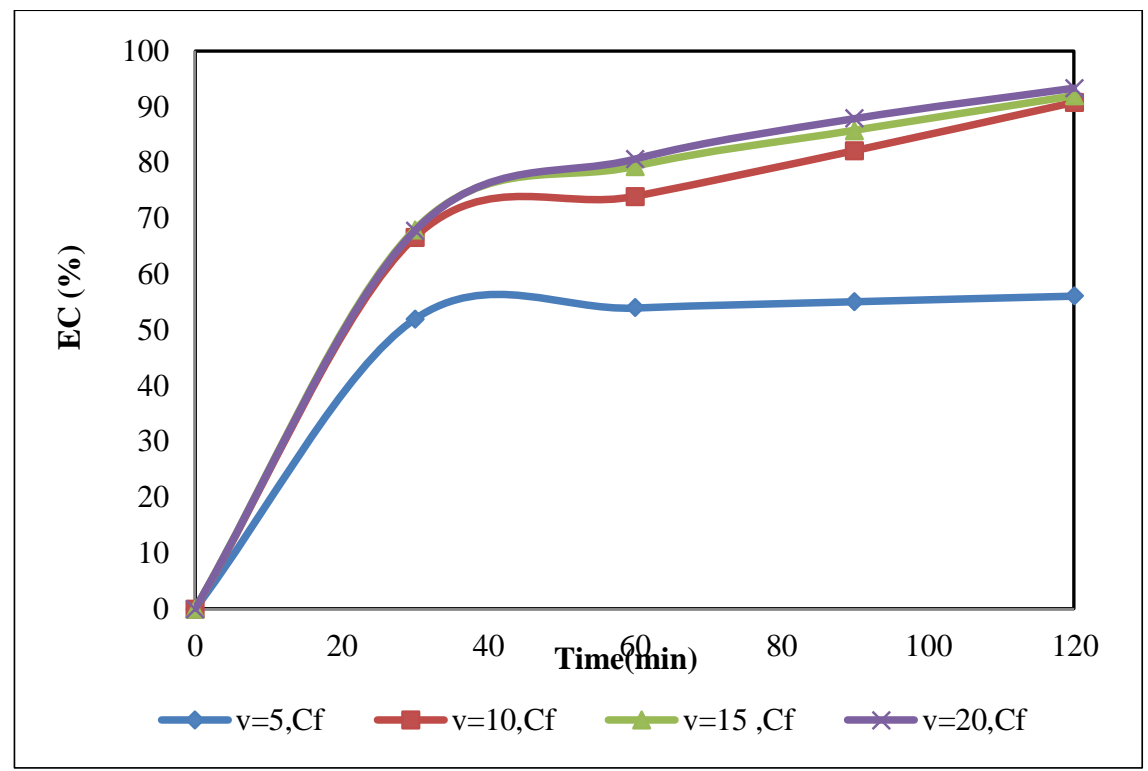

Figure 3. Effect of applied voltage on conductivity reduction efficiency

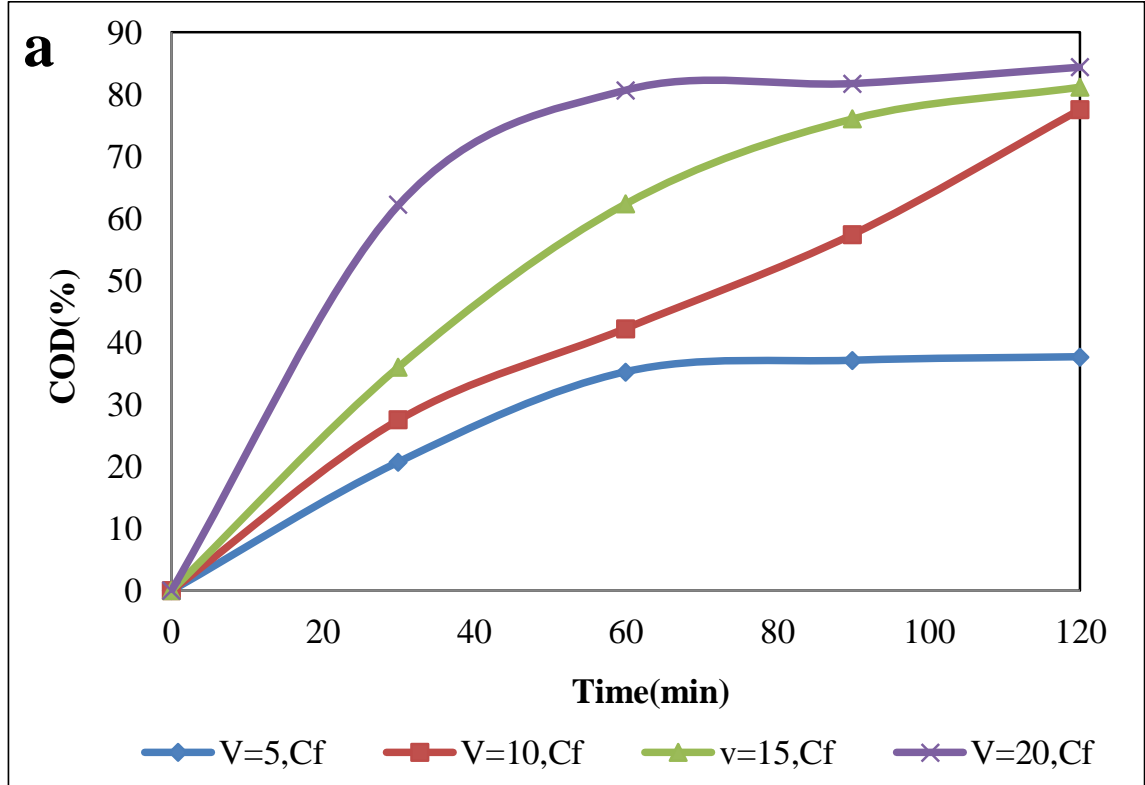




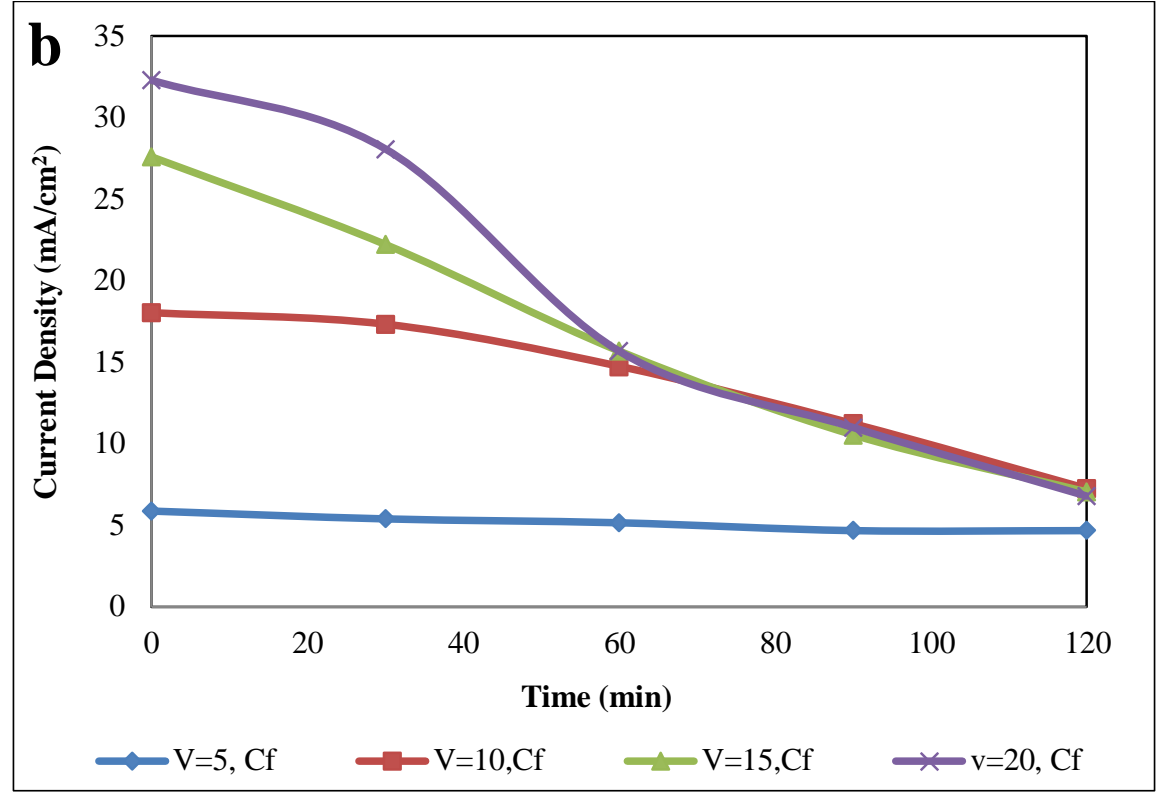

Figure 4. Effect of applied voltage on a) removal efficiency of COD and b) cell current density

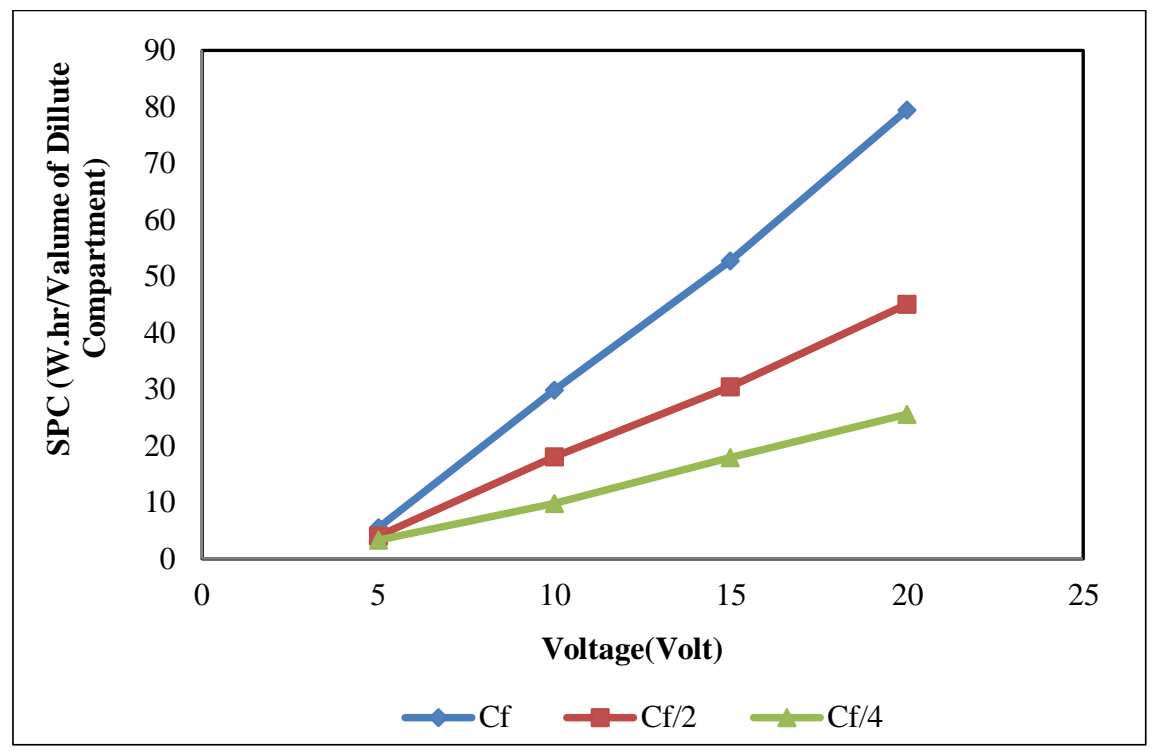

Figure 5. Effect of applied voltage on specific energy consumption

\subsection{Effect of Feed Concentration on EC and COD Removal}

In order to study the effect of feed concentration on EC/COD removal and energy consumption, experiments were carried out with three different concentrations of feed solution $(\mathrm{Cf}, \mathrm{Cf} / 2, \mathrm{Cf} / 4)$. These experiments were performed by using 1 lit of $0.02 \mathrm{M} \mathrm{H}_{2} \mathrm{SO}_{4}$ and $\mathrm{NaOH}$ as solutions of anode and cathode compartments, respectively for 120 min. Figure 6.a presents the variation of "EC reduction efficiency" and COD (as evaluating parameters) versus time. Here, applied voltage kept constant at $15 \mathrm{~V}$. Maximum efficiency ( 91\%) was achieved in the lowest initial feed concentration (Cf/4). The result was in accordance with similar study was done by Masigol et al, [44]. They have shown that using lower feed concentrations leads to obtain more ions removal efficiency. This can be explained by the fact that at lowest initial feed concentrations, total number of ions in the feed chamber is reduced. As a result, the cell electrical resistance is augmented thus leading to lowest EC so conductivity reduction" efficiency of feed chamber enhanced.

The variation of "COD reduction efficiency" with time as function of feed concentration has also been shown in Figure 6.b. Here we observed that the impact of using lower feed concentration on COD reduction is more significant in initial stages of experiment (operation time less than $60 \mathrm{~min}$ ). As time goes on, specifically higher than $60 \mathrm{~min}$, the effect of feed concentration becomes less significant. As a summary, both EC and COD reduction efficiency reach to their $90 \%$ maximum when ED process is performed for about $80 \mathrm{~min}$. 
To complete the study, influence of feed concentration on energy consumption and cell current density was also evaluated. As can be seen in Figure 7 ( $a$ and b), increasing the feed concentration results in higher cell current density, which obviously is due to existence of more ions into the feed compartment. Besides, less energy dissipation occurs when $\mathrm{Cf} / 4$ concentration was applied to the feed chamber.
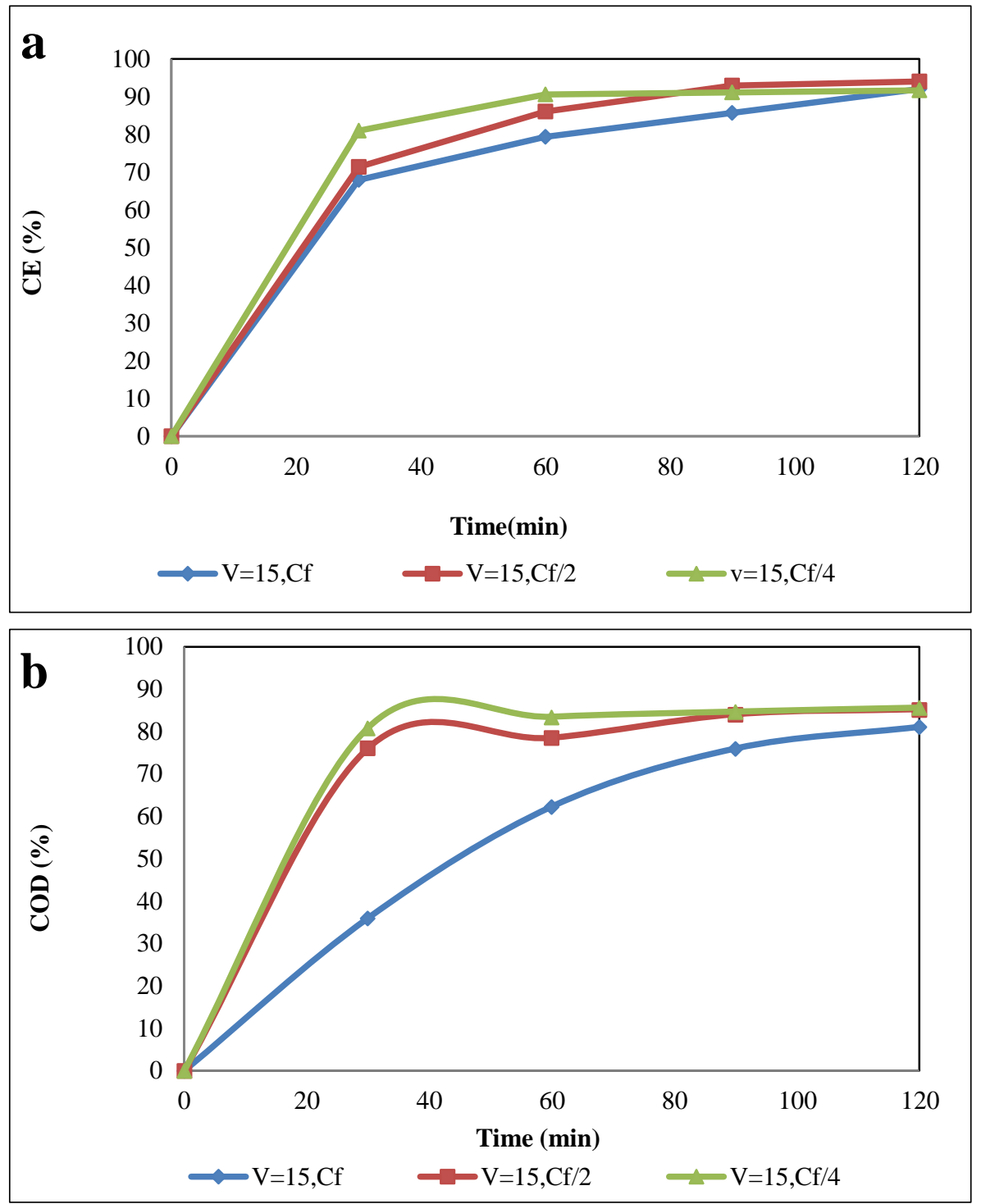

Figure 6. Effect of initial feed concentration on (a) EC reduction percentage and (b) COD removal percentage

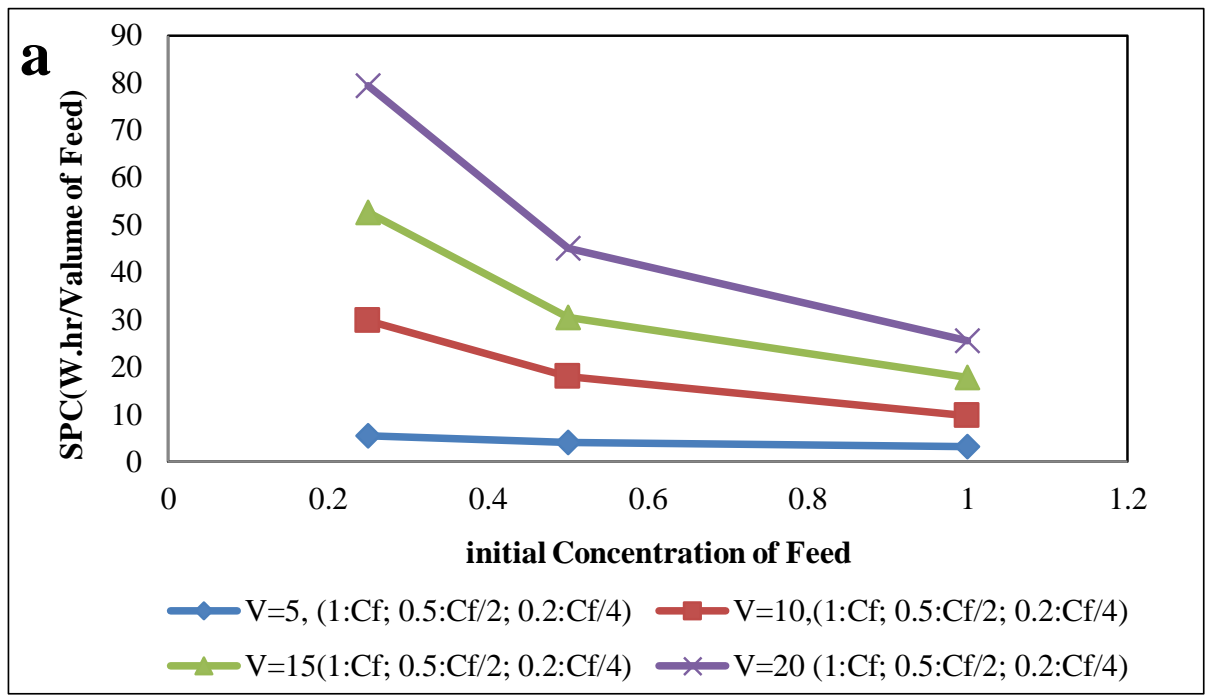




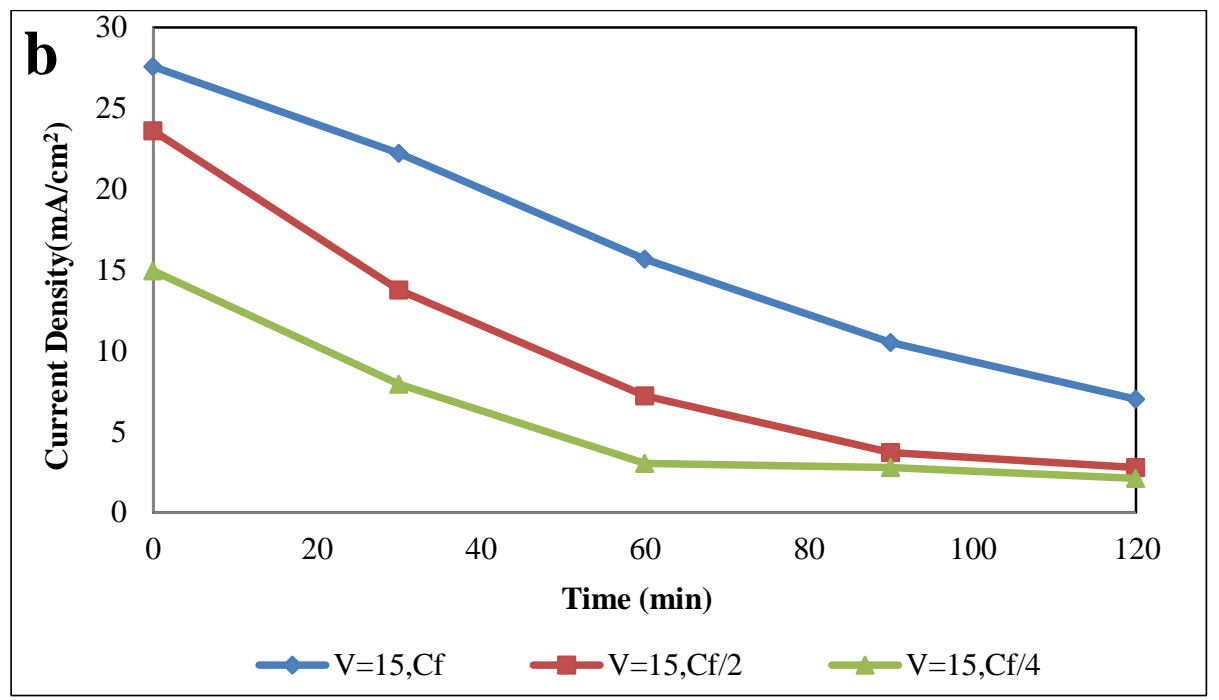

Figure 7. Effect of initial feed concentration on (a) specific energy consumption and (b) cell current density

\section{Conclusion}

In this work ED process was utilized for reducing electrical conductivity and COD of pre-treated wastewater. Here the major hypothesis was that efficiency of the ED process is directly dependent on cell applied voltage and feed initial concentration. Therefore, impact of these operating parameters was investigated on ED performances including the electrical conductivity reduction and removal efficiency of COD. In order to have better evaluation, ED energy consumption, as a limiting and crucial factor, was also studied. The results showed that applying ED can be considered as an optimal approach for reduction of EC and COD of wastes samples. By increasing the applied voltage and decreasing initial concentration of feed solution, both EC and COD reduction efficiency improved. As voltage increased from 5 to 20 volt, EC and COD reduction efficiency reached to their maximum values of $92 \%$ and $81 \%$, respectively in the $\mathrm{Cf}$ concentration. In addition, as the parameter of initial concentration decreased from $\mathrm{Cf}$ to $\mathrm{Cf} / 4, \mathrm{EC}$ and $\mathrm{COD}$ enhanced and reached to values of $92 \%$ and $85 \%$, respectively in the voltage of 15 . As an economical factor, although using higher voltages increase the efficiency of ED process, but there is a limitation for that since it simultaneously increases the total energy consumed by the device.

\section{Nomenclature}

$\mathrm{Cf}$

$\mathrm{Cf} / 4$

$\eta \%$

$\mathrm{COD}_{0}$

$\mathrm{COD}_{\mathrm{t}}$

$\mathrm{E}$

V

I

$\mathrm{t}$

$\mathrm{V}_{\mathrm{D}}$

$\mathrm{EC}_{0}$

$\mathrm{EC}_{\mathrm{t}}$

ED

EC

COD

RO lithium ions concentration in the feed solution (mol)

lithium ions concentration in the feed solution (mol)

COD removal efficiency percentage

Chemical oxygen demand at time zero $(\mathrm{mg} / \mathrm{L})$

Chemical oxygen demand at time $\mathrm{t}(\mathrm{mg} / \mathrm{L})$

Energy consumption (W.hr/L $\left.\mathrm{L}^{-1}\right)$

Applied voltage (V)

Cell current (Amp)

Operation time (s)

Initial volume of diluted compartment (L)

Electro conductivity of feed solution at time of zero $(\mathrm{ms} / \mathrm{cm})$

Electro conductivity of feed solution at time of $\mathrm{t}(\mathrm{ms} / \mathrm{cm})$

Electrodialysis

Electrical Conductivity

Chemical Oxygen Demand

Reverse Osmosis 


$\begin{array}{ll}\text { NF } & \text { Nanofiltration } \\ \text { IEM } & \text { Ion Exchange Membranes } \\ \text { CEM } & \text { Cation Exchange Membrane } \\ \text { AEM } & \text { Anion Exchange Membranes } \\ \text { LC } & \text { Limiting Current }\end{array}$

\section{References}

[1] Shu, Z., Lu, Y., Huang, J., Zhang, W. "Treatment of compost leachate by combination of coagulation and membrane process." Chines Journal of Chemical Engineering 24(2016): 1369-1374. https://doi.org/10.1016/j.cjche.2016.05.022.

[2] Bakhshoodeh, R., Alavi, N., Majlesi, M., Paydary, P. "Compost leachate treatment by a pilot-scale subsurface horizontal flow constructed wetland.” Ecological Engineering, 105(2017): 7-14. https://doi.org/10.1016/j.ecoleng.2017.04.058.

[3] M. Çakmakci, M., Özyaka, V. “Aerobic Composting Leachate Treatment By the Combination of Membrane Processes.” Waste Management \& Research 31 (2012): 187-193 doi: 10.1177/0734242X12462283.

[4] Trujillo, D., Font, X., S'anchez, A. "Use of Fenton Reaction for the Treatment of Leachate from Composting of Different Wastes.” Journal of hazardous materials 138 (2006): 201-204. https://doi.org/10.1016/j.jhazmat.2006.05.053.

[5] Hu, L., Liu, Y., Zeng, G., Chen, G., Wan, J., Zeng, Y., Wang, L., Wu, H., Xu, P., Zhang, C., Cheng, M., Hu, T. “Organic matters removal from landfill leachate by immobilized Phanerochaete chrysosporium loaded with graphitic carbon nitride under visible light irradiation. " Chemosphere 184 (2017): 1071-1079. https://doi.org/10.1016/j.chemosphere.2017.06.065.

[6] Umar, M., Aziz, H. A., Yusoff, M. S. "Trends in Use of Fenton, Electro-Fenton and Photo-Fenton for the Treatment of Landfill Leachate.” Waste Management 30 (2010): 2113-2121. https://doi.org/10.1016/j.wasman.2010.07.003.

[7] Manavi, N., Kazemi, A. S., Bonakdarpour, B. The development of aerobic granules from conventional activated sludge under anaerobic-aerobic cycles and their adaptation for treatment of dyeing wastewater." Chemical Engineering Journal 312(2016): 375384. https://doi.org/10.1016/j.cej.2016.11.155.

[8] Ward, A.J., Arola, K., Brewster, E., Mehta, C. "Nutrient recovery from wastewater through pilot scale electrodialysis." Water Research 135(2018): 57-65 https://doi.org/10.1016/j.watres.2018.02.021.

[9] Liu, R., Wang, Y., Wu, G., Luo, J., Wang, S. "Development of a selective electrodialysis for nutrient recovery and desali nation during secondary effluent treatment." Chemical Engineering Journal 322(2017): 224-233. https://doi.org/10.1016/j.cej.2017.03.149.

[10] Wang, Y., Li, W., Yan, H., Xu, T. "Removal of heat stable salts (HSS) from spent alkanolamine wastewater." Journal of Industerial Engineering Chemistry 57(2018): 356-362. https://doi.org/10.1016/j.jiec.2017.08.043.

[11] Dobrevsky, I. V., Pavlova, S. T. "Organic Matter Removal from Natural Waters by Electrodialysis Demineralization." Desalination 86 (1992): 43-48. https://doi.org/10.1016/0011-9164(92)80022-2.

[12] Hell, F., Lahnsteiner, J., Frischherz, H., Baumgartner, G. "Experience with Full-Scale Electrodialysis for Nitrate and Hardness Removal.” Desalination 117 (1998): 173-180. https://doi.org/10.1016/S0011-9164(98)00088-5.

[13] Lee, H. J., Oh, J., Moon, S. H. “Removal of Hardness in Fermentation Broth by Electrodialysis.” Journal of Chemical Technology and Biotechnology 77 (2002): 1005-1012. https://doi.org/10.1002/jctb.671.

[14] Kabay, N., Demircioglu, M., Ersiiz, E., Kurucaovali, I. "Removal of Calcium and Magnesium Hardness by Electrodialysis." Desalination149 (2002): 343-349. https://doi.org/10.1016/S0011-9164(02)00807-X.

[15] Lee, H. J., Hong, M. K., Moon, S. H. “A Feasibility Study on Water Softening by Electrodeionization with the Periodic Polarity Change. ” Desalination 284 (2012): 221-227. https://doi.org/10.1016/j.desal.2011.09.001.

[16] Deghles, A., Kurt, U. "Treatment of tannery wastewater by a hybrid electrocoagulation/electrodialysis process." Chemical Engineering and Processing: Process Intensification” 104(2016): 43-50. https://doi.org/10.1016/j.cep.2016.02.009.

[17] Tamersit, S., Bouhidel, K-E., Zidani, Z. "Investigation of electrodialysis anti-fouling configuration for desalting and treating tannery unhairing wastewater: Feasibility of by-product recovery and water recycling." Journal of Environmental Management 207(2018) 334-340. https://doi.org/10.1016/j.jenvman.2017.11.058

[18] Zhang, X., Li, C., Wang, X., Wang, Y., Xu, T. "Recovery of Hydrocholoride Acid from Simulated Chemosynthesis Aluminium Foils Wastewater: An Integration of Diffusion Dialysis and Conventional Electrodialysis.” Journal of Membrane Science 409 (2012): 257-263. https://doi.org/10.1016/j.memsci.2012.03.062.

[19] Mulyati, S., Takagi, R., Fujii, A., Ohmukai, Y., Maruyama, T., Matsuyama, H. "Improvement of the Antifouling Potential of an Anion Exchange Membrane by Surface Modification with Polyelectrolyte for Electrodialysis Process." Journal of Membrane Science. 417-418 (2012): 137-143. https://doi.org/10.1016/j.memsci.2012.06.024.

[20] Jing, G., Du, W., Guo, Y. "Studies on the Prediction of Separation Percent in the Electrodialysis Process Via BP Neural Network and Improved BP Algorithm.” Desalination 291 (2012): 78-93. https://doi.org/10.1016/j.desal.2012.02.002.

[21] Kabay, N., Arar, O., Samatya, S., Yuksel, U., Yuksel, M. "Separation of Fluoride from Aqueous Solution by Electrodialysis: 
Effect of Process Parameters and Other Ionic Species.” Journal of hazardous material, 153 (2008): 107-113. https://doi.org/10.1016/j.jhazmat.2007.08.024.

[22] Rohman, F. S., Othman, M. R., Aziz, N. "Modelling of Batch Electrodialysis for Hydrochloric Acid Recovery." Chemical Engineering Journal 162 (2010): 466-479. https://doi.org/10.1016/j.cej.2010.05.030.

[23] Parsa, N., Moheb, A., Mehrabani-Zeinabad, A. Masigol, M. A., "Recovery of Lithium Ions from Sodium-Contaminated Lithium Bromide Solution by Using Electrodialysis Process." Chemical Engineering Research and Design 98 (2015) 81-88. https://doi.org/10.1016/j.cherd.2015.03.025.

[24] Selvaraj, H., Aravind, P., Sundaram, M. "Four compartment mono selective electrodialysis for separation of sodium formate from industry wastewater." Chemical Engineering Journal 333(2018): 162-169. https://doi.org/10.1016/j.cej.2017.09.150.

[25] Merkel, A., Ashrafi, A. M., Ondrušek, M.” The use of electrodialysis for recovery of sodium hydroxide from the high alkaline solution as a model of mercerization wastewater." Water Process Engineering 20 (2017): 123-129. https://doi.org/10.1016/j.jwpe.2017.10.008.

[26] Lienhard, J." Electrodialysis shows potential for desalination of highly saline water.” Membrane Technology 2015 (2015): 7. https://doi.org/10.1016/S0958-2118 (15)30058-6.

[27] Luo, F., Wang, Y., Jiang, C., Wu, B., Feng, H., Xu, T. “A power free electrodialysis (PFED) for desalination.” Desalination 404(2017): 138-146. https://doi.org/10.1016/j.desal.2016.11.011.

[28] Sadrzadeh, M., Mohammadi, T. "Treatment of Sea Water Using Electrodialysis: Current Efficiency Evaluation." Desalination 249 (2009): 279-285. https://doi.org/10.1016/j.desal.2008.10.029.

[29] Valero, D., Garcia, V., Exposito, E., Aldaz, A., Montiel, V. “Application of electrodialysis for the treatment of almond industry wastewater.” Journal of Membrane Science 476(2015): 580-589. https://doi.org/10.1016/j.memsci.2014.11.007.

[30] Cui, L., Li, G., Li, Y., Yang, Bo, Zhang, L., Dong, Y. "Electrolysis-electrodialysis process for removing chloride ion in wet flue gas desulfurization wastewater (DW): Influencing factors and energy consumption analysis." Chemical Engineering Research and Design 123 (2017): 240-247. https://doi.org/10.1016/j.cherd.2017.05.016.

[31] Oren, Y., Linder, C., Daltrophe, N., Mirsky, Y., Skorka, J., Kedem, O. "Boron Removal from Desalinated Seawater and Brackish Water by Improved Electrodialysis.” Desalination 199 (2006): 52-54. https://doi.org/10.1016/j.desal.2006.03.141.

[32] Abou-Shady, A. "Recycling of polluted wastewater for agriculture purpose using electrodialysis: Perspective for large scale application.” Chemical Engineering Journal 323 (2017): 1-18. https://doi.org/10.1016/j.cej.2017.04.083.

[33] Sadyrbaeva, Zh." Removal of chromium(VI) from aqueous solutions using a novel hybrid liquid membrane-electrodialysis process." Chemical Engineering and Processing: Process Intensification 99 (2016): 183-191. https://doi.org/10.1016/j.cep.2015.07.011.

[34] Melnikov, S., Sheldeshov, N., Zabolotsky, V., Loza, S., Achoh, A.” Pilot scale complex electrodialysis technology for processing a solution of lithium chloride containing organic solvents." Separation and Purification Technology 189 (2017): 174-81. https://doi.org/10.1016/j.seppur.2017.07.085.

[35] Reig, M., Casas, S., Aladjem, C., Valderrama, C., Gibert, O., Valero, F., MiguelCenteno, M., Larrotcha, E., Cortina., J. L. ” Concentration of $\mathrm{NaCl}$ from seawater reverse osmosis brines for the chlor-alkali industry by electrodialysis." Desalination 342 (2014): 107-117https://doi.org/10.1016/j.desal.2013.12.021.

[36] Xu, X., He, Q., Ma, G., Wang, H., Nirmalakhandan, N., Xu, P. ” Selective separation of mono- and di-valent cations in electrodialysis during brackish water desalination: Bench and pilot-scale studies." Desalination 428 (2018): 146-160. https://doi.org/10.1016/j.desal.2017.11.015.

[37] Lemaire, J., Blanc, C. L., Duval, F., Théoleyre, M.A., Pareau, D. " Purification of pentoses from hemicellulosic hydrolysates with sulfuric acid recovery by using electrodialysis." Separation and Purification Technology 166 (2016): 181-186. https://doi.org/10.1016/j.seppur.2016.04.030.

[38] Chekioua, A., Delimi, R." Purification of H2SO4 of Pickling Bath Contaminated by Fe(II) Ions Using Electrodialysis Process." Energy Procedia 74 (2015): 1418-1433. https://doi.org/10.1016/j.egypro.2015.07.789.

[39] Rottiers, T., Van der Bruggen, B., Pinoy, L." Synthesis and transport of impurities in electrodialysis metathesis: Production of choline dihydrogen phosphate.” Membrane Science 541 (2017): 550-557. https://doi.org/10.1016/j.memsci.2017.07.042.

[40] Guo, H., You, F., Yu, S., Li, L., Zhao, D. "Mechanism of chemical cleaning of ion exchange membranes: A case study of plantscale electrodialysis for oily wastewater treatment." Journal of Membrane Science, 496(2015): 310-317. https://doi.org/10.1016/j.memsci.2015.09.005.

[41] Abou-Shady, A., Peng, C., Almeria, J., Xu, H. "Effect of pH on Separation of Pb(II) and NO3- from Aqueous Solutions Using Electrodialysis.” Desalination 285 (2012): 46-53. https://doi.org/10.1016/j.desal.2011.09.032.

[42] Wang, A., Nie, Y., Zhang, X., Zhang, S., Li, J. "Recovery of Ionic Liquids from Diluted Aqueous Solution by Electrodialysis." Desalination 285 (2012): 205-212. https://doi.org/10.1016/j.desal.2011.10.003.

[43] Fidaleo, M., Moresi, M., Cammaroto, A., Ladrange, N., Nardi, R., Soy Sauce Desalting by Electrodialysis.” Journal of Food Engineering 110 (2012): 175-181. https://doi.org/10.1016/j.jfoodeng.2011.06.002.

[44] Masigol, M. A., Moheb, A., Mehrabani-Zeinabad, A. “An Experimental Investigation Into Batch Electrodialysis Process for 
Removal of Sodium Sulfate from Magnesium Stearate Aqueous Slurry.” Desalination 300 (2012): 12-18. https://doi.org/10.1016/j.desal.2012.05.025.

[45] Keramati, N., Moheb, A., Ehsani, M. R. "Effect of Operating Parameter on NaOH Recovery from Waste Stream of Merox Tower Using Membrane System: Electrodialysis and Electrodeionization.” Desalination 259 (2012): 97-102. https://doi.org/10.1016/j.desal.2010.04.027.

[46] Yu, L., Guo, Q., Huo, J., Jiang, W. "Recovery of Acetic Acid from Dilute Wastewater by Means of Bipolar Membrane Electrodialysis.” Desalination 129 (2000): 283-288. https://doi.org/10.1016/S0011-9164(00)00068-0.

[47] Wei, Y., Li, C., Wang, Y., Zhang, X., Li, Q., Xu, T. "Regenerating Sodium Hydroxide from the Spent Caustic by Bipolar Membrane Electrodialysis.” Separation and Purification Technology 86 (2012): 49-54. https://doi.org/10.1016/j.seppur.2011.10.019.

[48] Wu, R. C., Xu, Y. Z., Song, Y. Q., Luo, J. A., Liu, D. “A Novel Strategy for Salts Recovery from 1,3-Propanediol Fermentation Broth by Bipolar Membrane Electrodialysis." Separation and Purification Technology 83 (2011): 9-14. https://doi.org/10.1016/j.seppur.2011.06.028.

[49] Masigol, M. A., Moheb, A., Mehrabani-Zeinabad, “A. Comprehensive Study on Interactive Effects of Operational Parameters By Using Response Surface Method for Sodium Sulfate Removal from Magnesium Stearate Aqueous Slurry via Electrodialysis Process.” Desalination and water treatment 57 (2015): 14145-14157. https://doi.org/10.1080/19443994.2015.1062426. 